\author{
Aleksander Jagiełło \\ Faculty of Economics, University of Gdańsk, Poland \\ https://orcid.org/0000-0002-4127-4150
}

\title{
CRITERIA FOR EVALUATION OF OFFERS IN TENDER PROCEDURES FOR CITY BUSES IN POLAND
}

\begin{abstract}
On the basis of the literature review and secondary research results presented in the article, it should be stated that the continuous modernization of the rolling stock used to provide collective urban transport services is one of the main tools to encourage urban residents to abandon the use of passenger cars for collective transport. In order to make the rolling stock modernization process as smoothly as possible, it is necessary to carry out and then settle tenders for city buses. In the article, the primary research on the criteria used to evaluate offers in tender procedures for city buses in Poland was presented using descriptive statistics. The article also attempts to discuss whether the current weightings of the price criterion and non-price criteria reflect their share in the total cost of the life cycle of the city bus.
\end{abstract}

Keywords: city bus tender, city bus market

JEL: R400, L910

\section{Introduction}

Changes in the public procurement law ${ }^{1}$, which occurred over the years, were aimed at limiting the contracting party's choice of a winning sale offer of urban transport fleet only on the basis of the "offered price" criterion. The presence of only this criterion led to the purchase of the cheapest available rolling stock. As proven by the analysis of the costs generated throughout the life cycle of the bus, the purchase

1 Among others: ustawa z dnia 29 sierpnia 2014 r. o zmianie ustawy - Prawo zamówień publicznych (Journal of Laws of 2014, item 1232) oraz ustawa z dnia 22 czerwca 2016 r. o zmianie ustawy - Prawo zamówień publicznych oraz niektórych innych ustaw (Journal of Laws of 2016, item 1020). 
of the cheapest vehicle may be associated with high costs of later use. A higher level of life cycle costs for the cheapest vehicles may result, among others, from higher costs of spare parts, higher fuel consumption and higher failure rates resulting in a lower level of technical readiness.

The criteria for the evaluation of tenders in tender procedures for city buses along with the description of the subject of the tender constitute the basic instruments in the process of selecting the most advantageous offers by the purchasers. The application of diversified offer evaluation criteria enforces competition between suppliers of rolling stock, not only on the price level but also on other non-price levels. Non-price competition tools among the rolling stock providers include: technical parameters of the rolling stock, delivery time of ready vehicles, offered warranty and service conditions as well as average energy consumption (electricity or fossil fuels). The purpose of the article is to examine whether the best possible criteria are used in tenders for city buses in Poland.

\section{The influence of quality of urban transport fleet on the demand for collective urban transport services}

Every year, about 3,700 million passengers use the services of collective urban transport in Poland (3,766.3 million - 2016; 3,739.4 million - 2017) (Local Data Bank, 2019). These services are carried out with the help of more than 12,000 buses, 219 trolleybuses and 3,204 trams (Local Data Bank, 2019). As evidenced by numerous studies on factors affecting the multiplicity of reported demand for urban transport services, one of the most important factors having the greatest influence is the quality of service provision (Wardman, 1994; Lythgoe, Wardman, 2002; Bresson et al., 2003; Balcombe et al., 2004; Paulley et al., 2006; Polat, 2012). The literature on the subject presents many factors that make up the general quality of urban transport perceived by passengers. These factors include: directness, frequency, availability, access to information, travel cost, reliability, speed, punctuality, rhythmicity, comfort, cleanliness and safety (Wyszomirski, 2008; Susilawati, Nilakusmawati, 2017). A large part of the above factors that make up the quality of urban transport services are directly or indirectly related to the technical condition and the age of the rolling stock used to provide services. As the research carried out in Gdynia proves, passengers traveling by public transport experience differences in the comfort of traveling with a new fleet, relative to the comfort of travel carried out by the senior fleet (Jagiełło, 2017). The above research show that the new rolling stock is better assessed by passengers than the older fleet in terms of:

- traveling comfort,

- arrangement of seating and standing,

- quality of visual information,

- smoothness of movement,

- noise intensity.

It was also proved that the higher comfort of traveling with new vehicles influences the shortening of the subjectively perceived travel time by passengers 
(Jagiełło, 2017). What is more, empirical research proves that with the increase of technical wear, mileage and age of the bus, the maintenance costs grow. The cost and labor consumption of repairs as well as the risk of breakdowns increases as the technical readiness and reliability of the bus decreases (Dyr, Misiurski, 2016; Potkány et al., 2018).

The results obtained in Gdynia in connection with the results referred to above (on the relation between the demand for urban transport services and the quality of services provided) suggest that rolling stock investments may have a positive influence on the increase in the use of urban public transport. This thesis is confirmed by the results of the research presented in the report: "Any Journey is Greener by Bus. Passenger experiences of modern bus services". According to the report, the cities being in opposition to the nationwide downward trend of the share of collective urban transport are cities rated as leaders in the implementation of innovative improvements to urban transport, as well as in the purchase of modern, ecological rolling stock (Any Journey is Greener by Bus. Passenger experiences of modern bus services, 2017). Summarizing the above considerations, it should be stated that the purchase of new buses is one of the key activities that carriers and public transport operators can take to increase the share of collective transport in modal split, and thus limit the use of passenger cars by urban residents.

\section{Tenders for city buses in Poland}

In the period 2013-2018, an upward trend was observed in the number of new buses registered for the first time in Poland. This trend, shown in Figure 1, concerned both buses in total, as well as the city bus segment itself (characterized by a large number of entrances and a large share of standing positions in the total capacity of the vehicle). There are two factors that are the reason for the increase in 2017-2018. The first of them are the changes regarding the approval requirements for the strength of the supporting structure of M2 and M3 category buses, which came into force in November 2018. These changes could have accelerated the releases vehicles by rolling stock manufacturers (InfoBus, 2018). The second factor is the introduction of electric buses and other low-carbon rolling stock on an increasing scale, also with the use of EU funds. 


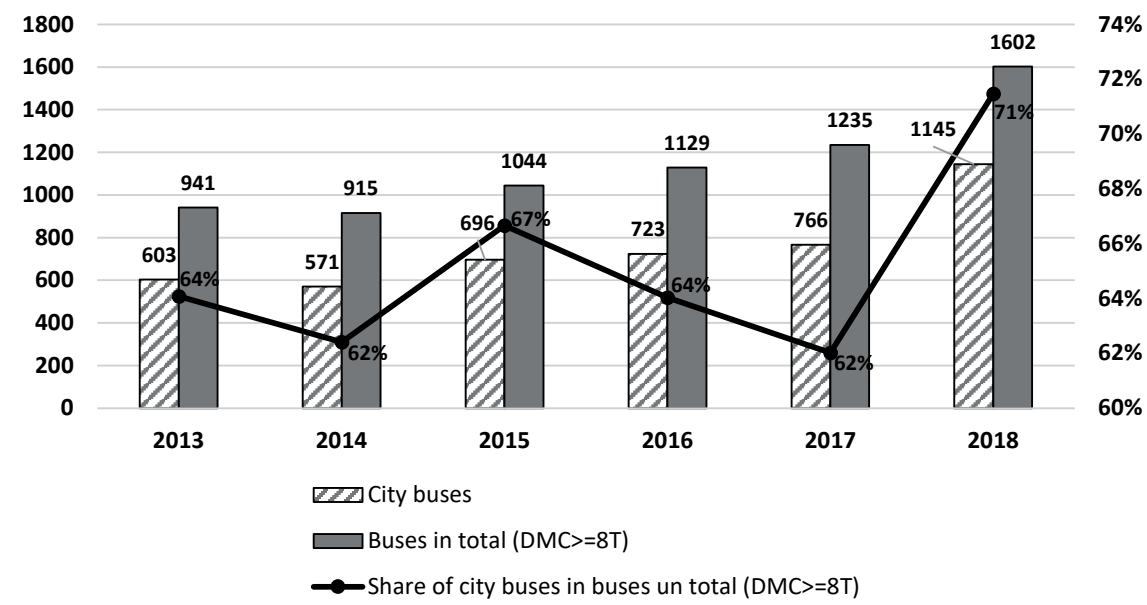

Figure 1. The number of new buses registered for the first time in Poland in 2013-2018 Source: (own study based on Rejestracje - autobusy, Statystyki - Grudzień 2018 r., 2018)

\section{Criteria for the evaluation of tenders in tender procedures for city buses in Poland}

As can be seen from the data presented in Figure 2, in most tenders for city buses that took place in Poland in 2017-2018, at least two non-price factors were used to rate the offers $(73 \%-2017 ; 69 \%$ - 2018). It was rare to use more than four non-price factors. According to the data presented in Table 1, the most important non-price criterion in tenders that took place in 2017-2018 were the technical parameters of the vehicles offered. The criterion "technical parameters" usually consists of a number of minor parameters, such as: engine capacity, engine brand, material used to construct the body and chassis frame and vehicle shell, suspension technology used, capacity, etc. It is worth noting that the importance of the price criterion, as well as the importance of individual non-price criteria, were characterized by a large range (area of volatility) in individual tenders in both 2017 and 2018. This means that individual entities organizing tenders to a different extent perceive the purchase price of a vehicle as good predictor of the total life cycle cost of the city bus.

In $2017-2018$, the price corresponded on average to $63 \%$ of the total offer evaluation submitted for the tender procedure (Figure 3 ). The low standard deviation is worth noting (9.05) and the coefficient of variation (14.4) of the price parameter in individual tenders. The results of the analyzes carried out show that the price criterion has on average twice the weight in relation to the most important non-price criterion. 


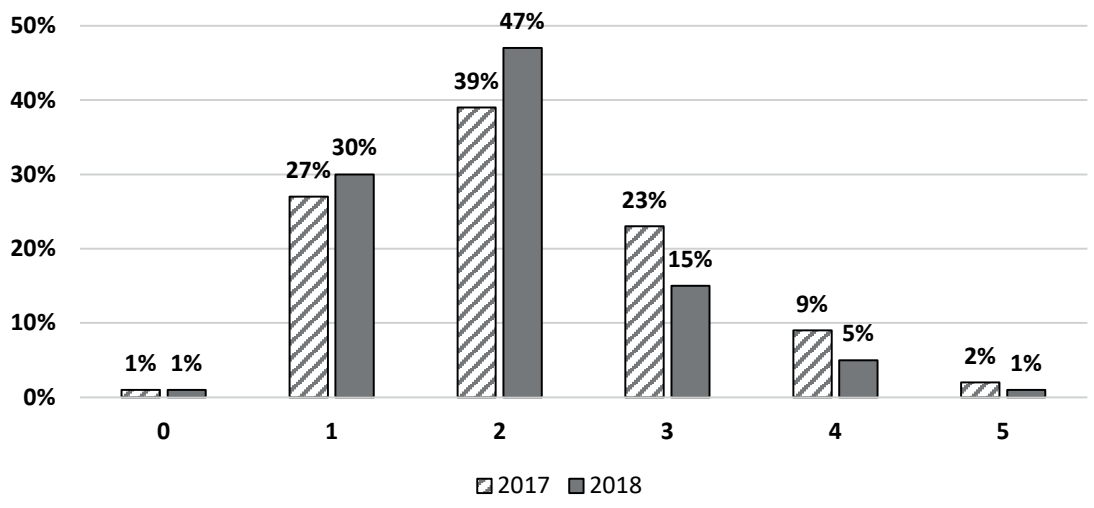

Figure 2. Number of non-price criteria applied in tenders for city buses in 2017-2018 Source: (own study based on primary data)

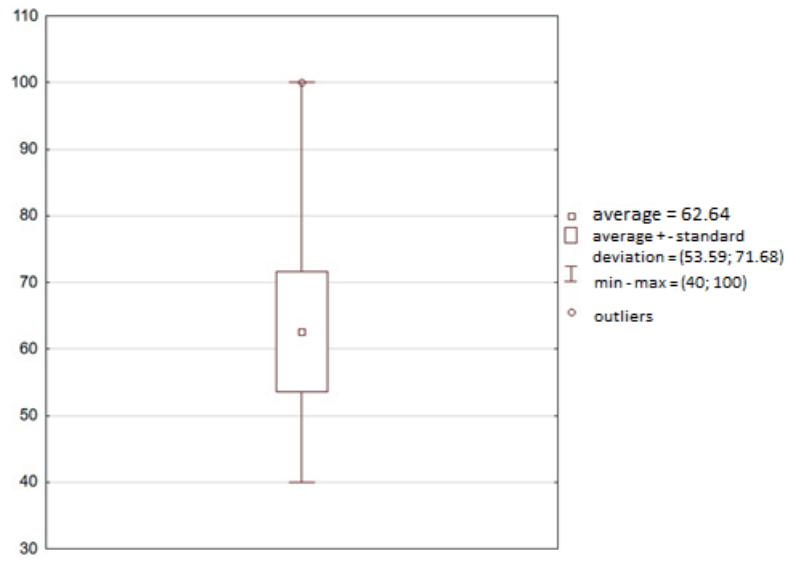

Figure 3. Percentage of points given for the price in tenders for city buses in 2017-2018. Source: (own study based on primary data)

Table 1. Importance of non-price criteria in tender procedures for city buses in 2017-2018 [\%]

\begin{tabular}{|l|c|c|c|c|c|c|c|c|c|c|}
\hline \multirow{3}{*}{ Criterion } & \multicolumn{10}{|c|}{ Weight criterion } \\
\cline { 2 - 14 } & \multicolumn{2}{|c|}{ Minimum [\%] } & \multicolumn{10}{|c|}{ Average [\%] } & \multicolumn{2}{c|}{ Maximum [\%] } & \multicolumn{2}{c|}{ Median [\%] } & \multicolumn{2}{c|}{ Dominant [\%] } \\
\cline { 2 - 14 } & 2017 & 2018 & 2017 & 2018 & 2017 & 2018 & 2017 & 2018 & 2017 & 2018 \\
\hline $\begin{array}{l}\text { Technical } \\
\text { parameters }\end{array}$ & 2 & 6 & 29 & 30 & 48 & 42 & 30 & 30 & 40 & 40 \\
\hline $\begin{array}{l}\text { Terms } \\
\text { of guarantee } \\
\text { and service }\end{array}$ & 2 & 4 & 13 & 11 & 40 & 30 & 10 & 10 & 10 & 10 \\
\hline $\begin{array}{l}\text { Fuel/ energy } \\
\text { consumption }\end{array}$ & 1 & 3 & 8 & 8 & 17 & 30 & 5 & 5 & 5 & 5 \\
\hline Delivery time & 4 & 2 & 7 & 8 & 20 & 40 & 5 & 5 & 5 & 5 \\
\hline Ecology & 1 & 5 & 6 & 12 & 25 & 35 & 5 & 9 & 10 & 10 \\
\hline
\end{tabular}

Source: (own study based on primary data) 
In individual tenders, in addition to the criteria listed in Table 1, factors such as: unification of assembled engines, price and availability of spare parts, payment date, comfort and safety of vehicles, level of vehicle readiness, possession of non-flammable certificates by the vehicle and the ability to recuperate electricity were also used as a criterion for evaluation of the tender.

\section{Results and discussion}

As it results from the analyzes presented in the article regarding the criteria for the evaluation of offers in tender procedures for city buses in Poland, price criteria are still the most important among the criteria used (with the average weight on average $63 \%$ ). However, as shown by the analysis of the share of the purchase cost of a vehicle in the total cost of a city bus, the cost of buying a city bus represents about $20 \%$ to $30 \%$ of the total cost of its life cycle (Ally, Pryor, 2016; Szumska, Sendek-Matysiak, Pawełczyk, 2018). Other significant components of the life-cycle cost of a city bus are costs related to the operation and maintenance of the vehicle (which include costs of labor and parts and materials) and energy costs (liquid fuels, gas or electricity), taking into account that the amount of individual costs included in the life cycle cost of the bus is strongly diversified between diesel-powered, hybrid, CNG / LNG-fueled buses and electric buses. The diversity in the amount of individual components of the bus life cycle costs is also influenced by the mileage that the vehicle does during its operation, and thus the amount of its operating work (Wolański, Wołek, Jagiełło, 2018). Taking into account the above considerations, the question should be asked whether the price criterion in tenders for city buses should not correspond to the share of the purchase cost of a vehicle in the total cost of a bus's life cycle. This would involve an increase in the share of other non-price criteria, such as: fuel consumption, unification and the price of spare parts, warranty period and conditions and the amount of external costs generated (by their share in the total cost of the city bus, while remembering that these shares are strongly diversified due to the type of drive used). In the near future, with the increase in the popularity of electric buses, new categories of criteria should be expected to be taken into account in tenders, in particular criteria for traction batteries.

\section{References}

Ally, J., Pryor, T. (2016), Life cycle costing of diesel, natural gas, hybrid and hydrogen fuel cell bus systems: An Australian case study, Energy Policy, 94, pp. 285-294.

Any Journey is Greener by Bus. Passenger experiences of modern bus services (2017), https:// greenerjourneys.com/wp-content/uploads/2017/02/LowCVP-Green-Bus-Dec-WEB.pdf.

Balcombe, R. et al. (2004), The demand for public transport: a practical guide, https://trl.co.uk/ sites/default/files/TRL593 - The Demand for Public Transport.pdf.

Bresson, G. et al. (2003), The main determinants of the demand for public transport: a comparative analysis of England and France using shrinkage estimators, Transportation Research Part A: Policy and Practice, 37(7), pp. 605-627.

Dyr, T., Misiurski, P. (2016), Prognozowanie kosztów utrzymania i eksploatacji taboru autobusowego, Problemy Transportu i Logistyki, 3(35), pp. 19-28. 
InfoBus (2018), Polski rynek nowych autobusów-09.2017, http://www.infobus.pl/polski-ryneknowych-autobusow-09-2017_more_99769.html [Accessed 12 January 2019].

Jagiełło, A. (2017), Zasadność inwestycji taborowych w zbiorowym transporcie miejskim na podstawie oceny komfortu podróży przez gdyńskich pasażerów, Zeszyty Naukowe Wydziału Ekonomicznego Uniwersytetu Gdańskiego, 75, pp. 127-136.

Local Data Bank (2019), www.bdl.stat.gov.pl [Accessed 2 January 2019].

Lythgoe, W.F., Wardman, M. (2002), Demand for rail travel to and from airports, Transportation, 29(2), pp. 128-143.

Paulley, N. et al. (2006), The demand for public transport: The effects of fares, quality of service, income and car ownership, Transport Policy, 13(4), pp. 1-22, doi: 10.1016/j. tranpol.2005.12.004.

Polat, C. (2012), The Demand Determinants for Urban Public Transport Services: A Review of the Literature, Journal of Applied Sciences, 12(12), pp. 1211-1231, doi: 10.3923/ jas.2012.1211.1231.

Potkány, M. et al. (2018), Comparison of the Lifecycle Cost Structure of Electric and Diesel Buses, Nase More, 65(4), pp. 270-275, doi: 10.17818/NM/2018/4SI.20.

Rejestracje-autobusy, Statystyki-Grudzień 2018 r. (2018). Available at: https://www.pzpm.org. pl/pl/Rynek-motoryzacyjny/Rejestracje-autobusy/Rok-2018/Grudzien-2018r [Accessed 1 February 2019].

Susilawati, M., Nilakusmawati, D.P.E. (2017), Study on the factors affecting the quality of public bus transportation service in Bali Province using factor analysis, Journal of Physics: Conference Series, 855(1), pp. 1-7, doi: 10.1088/1742-6596/855/1/012051.

Szumska, E., Sendek-Matysiak, E. Pawełczyk, M. (2018), Life cycle cost assessment of urban buses equipped with conventional and alternative propulsion drive, Prace Naukowe Politechniki Warszawskiej. Transport, 120, pp. 395-404.

Wardman, M. (1994), Forecasting the impact of service quality changes on the demand for interurban rail travel, Journal of Transport Economics and Policy, 28(3), pp. 287-306.

Wolański, M., Wołek, M., Jagiełło, A. (2018), Jak analizować efektywność finansową i ekonomiczną napędów alternatywnych?, Biuletyn Komunikacji Miejskiej, 148, pp. 6-12.

Wyszomirski, O. (2008) Transport miejski. Ekonomika i organizacja, Wydawnictwo Uniwersytetu Gdańskiego, Gdańsk.

\section{Corresponding author}

Aleksander Jagiełło can be contacted at: aleksander.jagiello@ug.edu.pl 